\title{
0 território paulistânico: um olhar existencial para além dos mapas antigos
}

Dossier Rede URbana e Definição das Fronteiras PaUlistas

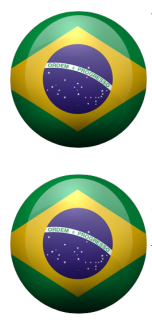

\section{Vitor Sartori Cordova}

Sociólogo. Doutorando do Programa de Pós-Graduação em Urbanismo pela Pontifícia Universidade Católica de Campinas. Campinas [SP] Brasil <vitorscordova@gmail.com>.

\section{Jane Victal}

Arquiteta e urbanista. Professora Pós-Doutora do Programa de Pós-Graduação em Urbanismo na Pontifícia Universidade Católica de Campinas. Campinas [SP] Brasil <janevictal@puc-campinas.edu.br>.

\begin{abstract}
Resumo
A Paulistânia fora denominada como a origem do campo de ação de um ser humano que mais tarde seria designado na literatura sociológica e antropológica como caipira, um tipo de homem que contemplava um modo de vida ligado às lides do trabalho campal. Entretanto, no período colonial, este território teria contornos imaginários, onde primordialmente seria reconhecido pela presença de pontos de permanência com habitações caracterizadas pelas técnicas utilizadas por este ser humano tanto no intuito de sua sobrevivência, quanto no auxílio de uma confecção paisagística que lhe forneceria relações simbólicas importantes em meio à uma vastidão de matas e caminhos a serem explorados. Desta forma, estas habitações revelar-se-iam como ponto nodal do surgimento deste território, oferecendo uma integração pautada pelo fator "tempo" e denunciando a passagem ou permanência do mameluco nesta região. Na ocasião, este território compunha-se de uma vastidão que englobava as áreas dos atuais estados de São Paulo, Paraná, Minas Gerais, Mato Grosso e Goiás, campo de influências e de exploração do antigo paulista nas incursões bandeirista e entradista. Ao longo do tempo, este território foi sendo repartido em áreas administrativas e reduzido às terras paulistas. Entretanto, onde houvesse o tipo humano em questão e as marcas de sua cultura material e imaterial, ali se encontrava a Paulistânia, tal como ficou registrado na literatura. Porém, este artigo também intenta apresentar a Paulistânia como origem do desenvolvimento do drama relacionado à existência caipira, se transformando não somente num arcabouço de relações causais entre meio, homem e luta, mas também num símbolo dos problemas humanos, ou seja, de um homem que tem a necessidade de se construir e de construir um mundo para si próprio.
\end{abstract}

\section{Palavras-chave}

Arquitetura vernácula paulista. Bandeirantes. Caipira. Paulistânia.

\section{The paulista territory: an existential look beyond the old maps}

\begin{abstract}
Paulistânia had been called as the origin action field of a human being who would later be designated in the sociological and anthropological literature as "caipira", a type of man who contemplated a way of life linked to the lusts of the field work. However, in the colonial period, this territory would have imaginary contours, where it would primarily be recognized by the presence of points of residence with dwellings characterized by the techniques used by this human being both the purpose of their survival and the aid of a landscape, providing them with important relationship in the midst of the forests and paths to be explored. In this way, these dwellings was the nodal point of the emergence of this territory, offering an integration guided by the factor "time" and denouncing the passage or permanence of the mameluco in this region. At the time, this territory consisted of a vast area that encompassed the regions of present-day states of São Paulo, Paraná, Minas Gerais, Mato Grosso and Goiás, a field of influence and exploration of the old São Paulo in the Bandeirista and Entradista incursions. Over time, this territory was being distributed in administrative areas and reduced to the lands of São Paulo. However, wherever there was the human type in question and the marks of its material and immaterial culture, there was Paulistânia, as recorded in the literature. However, this article also attempts to present Paulistânia as the origin of the development of the drama related to the caipira's existence, becoming not only a framework of causal relations between man and struggle, but also a symbol of human problems, which is a man who has the need to build yourself and also build a world for yourself.
\end{abstract}

\section{Keywords}

São Paulo's vernacular architecture. Bandeirantes. Caipira. Paulistânia. 


\section{Introdução}

Em termos de descoberta do solo, da fauna, da flora, dentre outros aspectos imprescindíveis para o europeu desbravar a nova terra, o nativo lhe serviu de guia. Dos índios que entraram na composição racial do paulista, os guaianazes foram os primeiros, concorrendo para o influxo de sangue indígena nas populações paulistas. Segundo Ellis Júnior (1926), além desse grupo, entrou na etnografia paulista os tamoios, os carijós, os tupinaés, os tememinós, os guaianazes e algumas tribos guaranis vindas do Paraguai. A base do cruzamento euro-americano foi o caldeamento com o guaianá preexistente no planalto onde, na primeira metade do século quinhentista, aportaram os portugueses.

De fato, o povoamento do sertão brasileiro pode ser classificado como algo que se inicia nas Capitanias do Sul, visto que a camada bandeirante que explorava o país pelos caminhos fluviais e indígenas já seria composta em primeiros momentos pelo indivíduo resultante do cruzamento euro-ameríndio, tendo ínfima participação do branco lusitano, exceto em pequenas incursões ao redor dos núcleos maiores. Isto, pois a exploração do hinterland não poderia ser feito de outra forma sem o conhecimento dos territórios ocupados por índios bravos, bem como da fauna e da flora para a busca de pedras preciosas ou de mão de obra silvícola, causa também do elemento afrodescendente ser quase ausente até meados do setecentos. Tal mão de obra só seria requisitada no século XVIII, nas explorações auríferas de Cuiabá e principalmente nas áreas cafeicultoras do interior do Estado de São Paulo conhecida por Oeste Paulista (Ellis Júnior, 1948).

Desta forma, já nos primeiros anos da colonização brasileira, a localidade da Vila de São Paulo de Piratininga se constituía em um posto avançado sobre o interior da América, se encontrando justamente no campo de alcance da cultura guarani. Sem mais alternativas para sua sobrevivência, o paulista se encontrou numa situação em que a escravização do nativo lhe serviu como oportunidade imediata. Por sua localização ser longe da Capitania do Norte, e sem muitos recursos o qual pudesse ambicionar, era o índio uma alternativa econômica, seja como mão de obra para construir ou reparar os seus pequenos engenhos e vilas ou como mercadoria para o ramo escravista (Zenha, 1970).

Muito raro os residentes de São Paulo de Piratininga terem outra forma de sobrevivência do que o comércio escravista de indígenas. Num isolamento nítido no qual se encontravam, estes contavam principalmente com o ingresso ao interior por parte dos apresadores para que sua economia fosse suprida. Fato pertinente é que tal ofício, durante dois séculos, foi o principal responsável pela segregação que a localidade sofria das demais nas terras da Metrópole. Tendo que permanecer por demasiada quantidade de tempo à busca de sua mercadoria, o pauperismo que se encontrava o colono (e também o pequeno vilarejo) era fruto de sua intimidade não só com o ofício, mas também com o indígena. Isto, pois o apresamento do índio foi um dos fatores responsáveis por muitos hábitos de comportamento social como a alimentação, as técnicas de combate, a língua falada (no caso, a língua geral, uma mistura entre o idioma português e o guarani), os muitos tipos de crenças criadas como a figura do curandeiro e do feiticeiro e, também, a poligamia, gerando assim indivíduos miscigenados. Por esta miscigenação entre lusitanos e índias, o mameluco, um indivíduo que se classificava não como índio ou português, mas sim um ser a partir dessa hibridização, ficou conhecido mais tarde como caipira (Candido, 1964). De fato, não teria muitos problemas para se integrar na sociedade que o concebeu, pois seus antepassados já a eram. Assim, fora chefe de bandeira, fundador de cidades, oficial da câmara, tabelião e comerciante.

Se no seiscentismo a busca por índios como meio de sobrevivência batia às portas fazendo com que o tempo despendido nas correrias em busca do nativo representasse uma rápida permanência nas nascentes "fazendolas" agrícolas das redondezas paulistanas, já a partir do século seguinte haveria mais tempo para a fecundidade, afetadas mais tarde pela exploração aurífera e tornando extensas as distâncias percorridas, levando a população a passar anos afora nos mananciais extrativistas. As consequências foram, naturalmente, o aumento do isolamento do planalto em relação à metrópole, fazendo com que os paulistas se desinteressassem do reino ao qual eram "ligados" e interrompido apenas pelo paulatino e diminuto afluxo de novos imigrantes lusos. A sua parca população, a sua pobreza de recursos de qualquer espécie, faziam dessa parte elevada da capitania vicentina um lugar esquecido e entregue exclusivamente quase a si mesma. Isso resultaria, segundo 
Ellis Júnior (1926), num núcleo de subsistência com pequenas culturas como a do milho, além da manutenção do hábito da pesca e da caça, adaptando as heranças da forma de habitar indígena às novas exigências.

Desta forma, o território seria fracionado em pequenos sítios, único regime permitido pelas circunstâncias que cercavam a colônia com o número reduzido de moradores desprovidos de recursos e obrigados a viverem em constante proximidade. De fato, o perímetro circundante da pequena área territorial que englobava as redondezas paulistanas, onde se estendiam esses sítios, passava por Parnaíba, Araçariguama, Apotribú, Caucaia, Quintaúna, Virapueiras, Cotia, Itapecerica, Jurubatuba, Itaquaquecetuba, São Miguel, Conceição dos Guarulhos, Tremenbé, Orubuapira, Juqueri e Atibaia (Ellis Júnior, 1926). Esse perímetro no seiscentismo foi a linha iniciadora dos arrabaldes da expansão paulista, não se falando dos pontos excepcionais mais longínquos atingidos por um ou outro sertanista que aí se fixava com sua gente e que, escapando à regra geral, se isolava no sertão formando novos núcleos de população.

Assim, muito pouco expressivas (isto é, produtivamente ao mercado externo) seriam esses sítios que, geralmente, compunham-se de uma casa de três lanços com o seu quintal e eram pessimamente mobiliadas, cujo conforto se resumia em toscos catres de dormir, raras cadeiras de estrado, algumas toscas prateleiras (onde eram guardados uns poucos pratos de estanho), peroleiras de vinho da terra e as tamboladeiras de barro. É muito possível também que essas casas servissem de sede para as indústrias agrícolas, como da fiação e tecido de algodão e lã, bem como do fabrico do açúcar nos muitos tachos que constituem o arsenal rural paulista, pois não se encontram outras edificações onde se pudesse colocar a feitura desses afazeres (Ellis Júnior, 1926). Nessas moradas, forçosamente teriam de se alojar todos os membros da família. Além dessa construção, geralmente os sítios tinham outras que talvez servissem de senzala para os escravizados índios ou moradia para os forros.

Além do mais, nos restantes das terras paulistanas, mais precisamente ao redor das casas, vigoravam algumas roças de milho, feijão, algodão e mandioca além de pequenos canaviais cuja garapa era transformada em açúcar nos tachos de cobre. De fato, os paulistas não tinham necessidade de tanta gente para a pequena lavoura, nem mesmo para o corpo de armas formados em suas primeiras incursões sertão adentro em busca do nativo, bastando a corriqueira organização comunitária, isto porque na época das bandeiras foi a pequena "propriedade" a constante. As sesmarias, cujas dimensões eram um pouco mais avantajadas, não chegaram a ser cultivadas ou habitadas sendo logo divididas e subdivididas em partilhas ou por intermédio das transmissões "causa mortis", ou seja, por meio de testamentos que muitas vezes não excluíam os filhos naturais, ou melhor, os filhos provindos extra conjugalmente (Ellis Júnior, 1926; Zenha, 1970). Desta maneira, o antigo paulista com seus atributos de temeridade e espírito ávido de aventuras evidencia-se também por seus laços comunitários desde os tempos das façanhas do bandeirismo.

Desta forma, o movimento das bandeiras acentuaria mais este comunitarismo, penetrando num sertão onde ninguém jamais ousaria se aprofundar. Não só os elementos naturais tornavam impossível o bandeirismo individual como, igualmente, os obstáculos humanos representados pelos índios antropófagos fariam degringolar qualquer tentativa que ousasse se isolar em terras inóspitas. A conformação geográfica do planalto paulista também teria influído na expansão bandeirante. As localidades paulistas situadas na crista do planalto, que se iniciava na serra do Mar, tinham os seus rios correndo não em direção ao litoral como acontecia nas outras capitanias, mas em direção oposta, onde encontravam outros caudais navegáveis à canoa que, subindo a margem direita desses grandes cursos, se internava no interior do continente sul-americano até às suas nascentes nos Andes (Ellis Júnior, 1948; Holanda, 1945). Pelas agruras do solo e devido à formidável densidade das florestas, os paulistas tiveram que organizar as suas incursões com a ausência de equinos devido a dificuldade do percurso além-litoral. Não tendo podido assim proceder, tiveram que andar a pé, do que resultou para eles serem andarilhos incansáveis. Além do mais, a iniciativa a pé, devido também a proximidade dos vizinhos que poderiam ser alcançados da mesma forma, só mais reforçariam o sentimento comunitário desta população. Além disso, este comunitarismo abundava não só nas iniciativas econômicas e políticas, mas nas culturais, vide os tantos contos folclóricos, os modos culinários e a forma de suas habitações. 
Desta maneira, a dilatação sertaneja, num acentuado ritmo de conhecimento topográfico e toponímico, envolvendo os ranços comunitários desde os tempos bandeirísticos e dos costumes dados à miscigenação, moldaria outras práticas de sociabilidade, ou melhor, outras possibilidades de existência. Tais possibilidades se amalgamariam num território conhecido por "Paulistânia", região que coincidia com o planalto paulista e paranaense até as ribanceiras do rio Iguaçu de um lado e do rio Paraná de outro, juntamente com a região alta catarinense, a serrana rio-grandense e a do estado do Rio de Janeiro do vale médio do rio Paraíba. Entretanto, tal território amplo e intangível não seria delimitado por questões administrativas assim como se dava pela divisão sesmarial da coroa portuguesa, e sim por um aspecto mais sutil, como no das casas destes andantes paulistas. Estas se apresentariam como a única forma mais palatável a um ser humano acostumado à migração, pontuando o território explorado tanto nas incursões das bandeiras como das entradas. Mesmo quando o mameluco fora forçado ao sedentarismo e se tornando o conhecido caipira, não deixaria de representar o significado deste território para formação de seu ser. Esta representação contemplaria algumas construções que complementariam as suas visões não só do seu trabalho, mas até mesmo as sobrenaturais, que seria nada mais que o bairro rural com sua capela, sua venda e demais casas do núcleo familiar, ou seja, a mais nova possibilidade existencial encontrada posteriormente por ele (Candido, 1964).

\section{Fundamentos da habitação paulista: a casa indígena}

Primeiramente é importante estabelecer as origens da arquitetura vernácula paulista. Tal arquitetura vernácula foi sempre inundada pela influência indígena da família guarani. Se bem observado, a habitação nativa, por exemplo, é conseguida através de madeiras roliças fincadas no chão e vergadas superiormente, definindo um espaço com aspecto abobadado onde se predomina a linha curva. Toda a estrutura é recoberta de palha visando o isolamento térmico, porém, prevendo-se pequenas aberturas de entrada de luz e ventilação. A oca indígena é escura, mas fresca. Portadores de uma cultura característica de região florestal em que as atividades de subsistência incluem as lidas da caça em combinação com o tamanho da terra, os guaranis se estabeleceram, sempre que possível, no seio da mata, evitando a paisagem aberta dos campos. As suas aldeias, longe de constituírem conglomerados compactos de habitações, consistem em casas mais ou menos distantes uma das outras, espalhando-se pelas clareiras abertas na floresta.

Entretanto, fica impossível determinar um "centro" da aldeia, a não ser que se considere a habitação do ñanderú, médico-feiticeiro ou o oýguatsú, a casa das festas religiosas (Schaden, 1962). De fato, a construção em que se realizam as cerimônias é ponto de convergência das atividades sociais e religiosas do grupo, de modo que as aldeias maiores, em que haja dois ou mais chefes religiosos, tendem a decompor-se em outros tantos núcleos bastante independentes, cada qual com sua vida própria. Na maioria dos casos, essas unidades sociais constituem parentelas sob a direção de um chefe de família-grande. Ao passo que, outrora, a família-grande que constituía uma comunidade de produção, de consumo e de vida religiosa, morava em uma só habitação suficientemente espaçosa para abrigar várias pessoas.

A casa grande, construção típica de numerosas tribos do grupo guarani, é um dos elementos mais imponentes da cultura material da família Kayová (Schaden, 1962). Chamam-na tapýguasú (cabana grande) ou óga-djekutú "casa fincada", (kutú significa fincar, cutucar) ou, em português, "casa beirachão". Além da base quadrangular, duas são as suas características essenciais: a cobertura, descendo até o chão formando os frontões e a cumeeira que não tem suporte. 0 feitio geral é o de canoa emborcada, com os oitões "em forma de ogiva". A casa, primordialmente, consiste em quatro faces de cobertura que fecham todos os lados, estendendo-se a cumeeira em sentido norte-sul. Há, na verdade, três entradas: uma a leste, outra ao norte e a terceira ao sul. Em frente, isto é, para leste, estende-se um grande pátio onde se dá num terreiro de dança. Já na parte interior, esta se compõe de quatro grandes vigas transversais, duas à direita e duas à esquerda da entrada principal, repousando sobre as vigas longitudinais contra as quais se apoiam as ripas da parede-cobertura fincadas no solo. Do lado oposto à entrada principal, há um "altar" confeccionado por uma armação de madeira, diante da qual se realiza parte das danças religiosas. A óga-djekutú é de construção sólida, que resiste às intempéries durante muitos anos e, do ponto de vista arquitetônico, segundo Schaden (1962), guarda outras características importantes: a falta de separação ou divisão entre cobertura e parede e a ausência de suportes para a linha central da cumeeira. 
Todavia, deve-se atentar ao fato de que a oca indígena representa mais uma relação homem-natureza do que uma suposta eficiência econômica do indivíduo, o qual não encontra fundamento algum em termos de prestígio social. Para tal, existem duas razões principais: em primeiro lugar a feição predominantemente comunitária de produção e consumo e, em segundo, a orientação da cultura dado à comunhão com o sobrenatural. 0 primeiro destes fatores faz com que o estímulo para o trabalho se relacione estritamente com a intensidade do sentimento de solidariedade. Já o segundo se conecta com o caráter religioso e a constante preocupação com os problemas de seu destino.

Há aqui grande predomínio da religião em todas as esferas da cultura, inclusive na economia, a ponto de as atividades econômicas aparecerem como simples pretexto para a realização de cerimônias de contato com o sobrenatural e controle dos poderes pessoais que se julgam ter influência no destino dos homens. Quer seja um mutirão para a colheita dos produtos da roça ou a partida para uma viagem ou aparecimento de qualquer fenômeno inesperado, tudo pode ser motivo para rezas e danças rituais (Schaden, 1962). Desta maneira, a casa tradicional guarani satisfaz a uma série de requisitos de sua organização social e religiosa. Constitui abrigo ideal para o conjunto de famílias elementares que, congregadas em família-grande sob a égide de um chefe único, forma estreita comunidade de vida com interesses econômicos, políticos e, obviamente, religiosos em comum.

\section{A casa tradicional paulista}

O mameluco do século XVII foi o protagonista da união entre conhecimento arquitetônico herdado da península ibérica com adaptações nativas. Como exemplo deste sincretismo construtivo, tem-se a taipa de pilão. Esta foi largamente adotada, pois no âmbito do hinterland paulista não havia materiais disponíveis para a utilização, por exemplo, da alvenaria de pedra. Todavia, no litoral vicentino, além deste material, também dispunha-se a cal. Estes materiais foram utilizados principalmente na construção do primeiro engenho de moer cana trazida por Martim Afonso de Souza por volta de 1533, tarefa que não foi bem sucedida mudando-se esta indústria para a Bahia e Pernambuco. 0 açúcar em São Paulo só vingou bem mais tarde, principalmente nos idos anos do século XIX, exceto alguma ou outra produção contundente para abastecer Minas Gerais na época do ouro no século XVII e XVIII.

Mesmo assim, a arquitetura de cal e pedra não perdera a ligação que tinha com a forma de construir do reino, mantendo-se esteticamente bem próxima. Entretanto, se o português trouxe a técnica construtiva, os estilos, as variações formais para tentar fazer do novo continente uma "nova Lisboa", o próprio meio exigiria outros procedimentos tanto pelo material fornecido pelo local quanto pelo isolamento com respeito a metrópole que se encontravam, inviabilizando o passo a passo tradicional. Como exemplo da necessidade desta mudança tem-se a Serra do Mar que, durante muito tempo, continha uma antiga trilha indígena de difícil passagem onde os transeuntes subiam setecentos e cinquenta metros de joelhos, não podendo levar nada além do que fosse humanamente possível. Assim, no artifício construtivo, facilitado era o acesso à taipa, matéria prima de muita abundância e única fonte disponível aos habitantes do além-litoral. Segundo Lemos (1979), o padre Afonso Brás talvez tenha sido o pioneiro da técnica de taipa de pilão. Este, logo transformou o rancho de palha dos jesuítas em casa de taipa de pilão, possivelmente se tornando o introdutor desta técnica em São Paulo. Esta vila, em seu antigo lugar de nascimento, não tinha pedra de espécie alguma e mesmo a intenção de seu transporte era difícil devido aos empecilhos descritos. Além do mais, os tijolos cerâmicos estavam fora da tradição lusitana da época. Desta maneira, as construções paulistanas dos primórdios apelaram ao que tinham, literalmente, à mão.

Logicamente que o componente cultural predominante era o do lusitano construtor que trouxe seus costumes, modos e solução estrutural, mas, numa sociedade onde o elemento indígena adentrava cada vez mais, estes costumes acabavam sendo utilizados de um modo muito particular. Mesmo podendo a forma ser ibérica no aspecto das casas urbanas dos paulistas mamelucos nos núcleos centrais, as casas da roça mostravam outras conotações a elementos lusitanamente conhecidos (Lemos, 1969). Como exemplo, tem-se o alpendre. Em Portugal, este aparato arquitetônico servia como sequeiro de cereais. Já no Brasil, a faixa fronteira passou a servir de recepção, onde convivia também com os cômodos laterais transformados em espaços para ferramentas e empregados. Isso porque em São Paulo do período colonial, bem diferente de Portugal, a população rural não se reunia em pequenas aldeias. Cada um morava em seu quinhão de terra e, por menor que 
fossem estas, a distância às vilas pelo estado das estradas era penosa. Desta forma, as paradas para dormir eram obrigatórias e, para o viajante estranho ou conhecido, nada melhor do que encontrar nas casas dessas paragens um quarto ou o chamado "corredor" (alpendre) para descansar e prosseguir no dia seguinte.

Todavia, segundo Lemos (1969), para um estudo criterioso à respeito dos alpendres tradicionais, estes seriam encontrados com mais frequências nas capelas paulistas, como nos exemplos urbanos que, dentro da tradição ibérica, provêm da basílica romana. Derivariam dos templos providos de galilés, locais de reunião de irmandades e onde eram enterrados os mortos ilustres. Dentro desta filiação está também o alpendre das igrejas das reduções jesuíticas do Paraguai, onde as determinações canônicas separariam os índios pagãos, os catecúmenos dos outros já doutrinados, denunciando a verdadeira orientação dessa solução arquitetônica. Já em relação aos alpendres das igrejas rurais, algumas hipóteses surgiriam pela frente: ou foram copiados de exemplares urbanos ou surgiram através de processos vários, mas que sempre encerram os empréstimos de soluções pertinentes à arquitetura particular, enfeitando e emprestando à capela certa dignidade de casagrande. Situadas em propriedades particulares e levantadas pelo interesse dos donos das terras, algumas eram construídas por gente importante na sociedade bandeirante, por pessoas de grande destaque devido ao cabedal que dispunham. Desta forma, não bastavam aos potentados mamelucos o "cabedal em arcos", o dinheiro, a ascendência sobre o povo, ou seja, não bastavam as glórias e proveitos materiais. Era preciso, também, tratar dos bens espirituais e providenciar obras que tornassem a igreja agradecida.

Neste viés, poder-se-ia relacionar ao alpendre residencial a mesma função selecionadora do alpendre da capela, ou seja, hóspedes estranhos e empregados administrados não entravam na casa. Contudo, crê-se que estes exemplos dados por Lemos (1969) sobre a função do alpendre caracterizariam muito mais a sociedade paulistana dos anos oitocentos, pois, nos sítios paulistas de outrora, as necessidades construtivas do alpendre se interligavam com a corriqueira solidão em que se encontravam os residentes pelas grandes distâncias. Reconhece-se que o exercício religioso neste "corredor" teria importância, pois se cada vila portuguesa tinha sua igrejinha, no Brasil cada um tinha que providenciar seu altar. Entretanto, pautar a função do alpendre doméstico como o mesmo que o do eclesiástico europeu seria inconcebível, já que a separação entre forros e livres só faria sentido numa sociedade onde a estratificação social seria nitidamente sentida pela distinção de posse, padrão societário impensável, por exemplo, nos seiscentos. Mesmo que a explicação da função dos alpendres paulistas se interligasse estritamente como provindo da moral cristã, esta também caducaria facilmente, pois tais padrões nunca foram bem implantados como assim outrora desejavam os jesuítas (Candido, 1999).

Outros exemplos desse sincretismo miscigenatório e arquitetônico podem ser encontrados nas cozinhas das casas paulistas mais rústicas, que ficavam na parte exterior e descoladas da casa devido ao calor que produziam seus fornos à lenha. É neste ponto que pode a casa bandeirista dos primeiros tempos se parecer com a oca indígena, visto a localização do cozimento dos alimentos geralmente feitos no jirau devido à falta de ventilação e pela constante obscuridade. Aqui, vê-se que a temperatura dos trópicos também influenciou nas improvisações dessas edificações construídas como anexos (e isso até nas casas urbanas). Desta forma, a cozinha parecia significar que era mesmo uma edificação independente, tendo-se registros de moradas na vila que continham "casinhas no quintal" ou uma casa de taipa de pilão coberta de telha "no cabo do quintal das mesmas casas". Já outros inventários acrescentam à descrição da casa principal "uma casinha de taipa de pilão coberta de telha no mesmo quintal" e os demais, depois de mencionarem os lanços principais, enumeravam a cozinha como um aposento no quintal, tudo de taipa de pilão e coberto de telha (Bruno, 1977). Entretanto, como observado, dentre as várias improvisações utilizadas, sempre há uma constante: a taipa, se tornando símbolo construtivo e de identidade paulista, podendo chegar a se afirmar que "onde há taipa, há paulista" (Lemos, 1979).

Contudo, vale lembrar que a palavra "casa", que sempre aparece nos documentos antigos sobre a morada paulista, designava primordialmente qualquer aposento da habitação, classificando-se estes com a palavra "lanço", que significava uma série de cômodos encarreirados formando uma fila perpendicular ao terreiro. Segundo Lemos (1999) era possível dizer "um lanço de casa", "morada de casas rasteiras", "casa de banhos", "casa de farinha”, "casa de moenda", etc. Isso pode ser explicado 
pela forma de comportamento que o paulista adotava em cada um desses cômodos. Exemplo maior é a própria cozinha, pois, sendo um lugar de preparo de refeições e onde se comia, também era utilizada para permanecer durante o dia. Já a sala da frente, que era um lugar de se receber visitas, também era um local utilizado para trabalhos artesanais. Enfim, as atividades transbordavam os compartimentos que lhes eram destinados, indo se encontrar em outros ligados geralmente pela união entre o fogão à rua, a varanda alpendrada com os fundos, o quintal à outros quintais, influenciando a forma do lote onde a casa se encontrava.

Desta maneira, a casa paulista, na verdade, era toda fracionada com inúmeras construções-satélites. Sendo assim, ao lado da casa principal ficava: o telheiro da cozinha geral, os quartos para os hóspedes e subalternos (que, na maior parte das vezes, eram tropeiros), os depósitos de trigo e milho, o moinho, a casa de fazer farinha, o monjolo, o galinheiro, o curral, a moenda de fazer garapa, o pomar, tudo protegido por cercas de madeira ou por muros de taipa. Se os quintais eram cercados, era só pra separar os pomares do gado que ficava solto ou para proteger os animais domésticos dos selvagens e também para evitar sua fuga. Entretanto, mesmo cercados, eram quintais imensos, com várias entradas e saídas. Entradas e saídas estas que se compactuavam com as distâncias entre as unidades de vizinhança, com as viagens à vila, aos centros de consumo, às festas religiosas nos dias santos, às sessões de vereanças dos homens-bons, caindo exatamente nas estradas. Estas, segundo Lemos (1999), muito ruins, pois, quando chovia, inundavam, encharcavam ou até mesmo caíam-se as pontes. Isto avulta mais uma vez um fato relevante: o hábito da hospitalidade imprescindível, indo além do acolhimento cordial. Era assim esta hospitalidade uma obrigação social que garantia a sobrevivência dos membros da comunidade.

Em se tratando do termo comunidade, havia um ponto que igualava as famílias mais abastadas das menos favorecidas: a sua proteção. Por questões de princípio, as mulheres nunca apareciam aos estranhos, só a parentes mais chegados, ficando assim no pretório, ou seja, na varanda que eram utilizadas como forma de isolar as mulheres dos olhares alheios. Contudo, este isolamento não as alienava dos assuntos tratados nos alpendres ou nas varandas da casa principal. Somente era uma forma de "incluí-las de forma mais digna". Ali, no lugar onde elas não poderiam se prontificar a estar sem o consentimento patriarcal, davam-se ordens aos agregados, comprava-se ou vendia-se mercadoria, acolhia-se os hóspedes, oferecia-se refeições aos passantes que ali pediam, distribuíase os serviços aos parcos escravizados e, logicamente, organizava-se os cultos religiosos.

\section{0 modo de habitar paulista}

No território paulista é mais do que conhecida a atuação do mestiço bandeirante além das fronteiras da chamada "borda do "campo". Indo descer índios ou em busca de metais preciosos, esse antigo paulista sempre estava em curso, seja por terra nas picadas das matas abertas pelo conhecimento advindo do índio ou por meio dos rios com suas toscas embarcações que mal venciam as águas bravias. Entretanto, a atuação do paulista dos primeiros anos sempre designou-se por atividades de trato comunitário. Desta fase, algumas implicações arquitetônicas chamam a atenção: as moradias pelos caminhos e entroncamentos das trilhas deixadas no sertão. Mesmo que mais tarde, além das épocas do açúcar do seiscentismo e setecentismo, este tipo de arquitetura vernácula paulista fosse fundida com a mineira na época da fase de descoberta do ouro, ainda guardaria tênues relações construtivas com a taipa. Taipa esta que mancomunava-se também com o isolamento do resto do "mundo civilizado", caracterizando assim o planalto piratiningano. A Serra do Mar, adversário implacável, exilava os homens de qualquer comunicação mais facilitada, além de deixar aquele que se aventurava num desconforto de tudo que se poderia adquirir com mais rapidez de algum navio ou outro que aportava no litoral vicentino, como os próprios materiais construtivos e especialistas na profissão edificatória.

Outros fatores vieram ao auxílio dessa situação difícil da capitania sulina: o pauperismo, que exigia da população uma vida parcimoniosa, guardando tudo o que viesse do reino, desde uma simples fivela de calçado até um raro vestido de veludo, deixando-os nos seus inventários como peças de bem de valor quase incalculável, mais do que a própria terra. Além do mais, improvisações é que não faltavam. E, neste quesito, no que diz respeito à sobrevivência, o ramo apresador apresentavase como a forma mais rápida. Todavia, deste contato estabelecido com o índio, até a língua doméstica se diversificaria. A língua geral era tão utilizada que mal o português conseguia sair da boca 
sem um grande esforço. Enfim, na sua habitação, algumas atividades decorridas deste isolamento eram corriqueiras: o convívio com estranhos andarilhos, a vida doméstica caracterizada pela vida intramuros (principalmente mulheres) e o trabalho caseiro em seus minguados sítios.

Como o exemplo das tradições indígenas nos trabalhos caseiros em São Paulo, em consequência da intensa absorção dos elementos culturais nativos pelos escassos povoadores brancos de meados do século dezesseis, compreende-se o cultivo da mandioca e o preparo da farinha. Estas práticas de cultivo se tornariam comuns no planalto, pois na segunda metade desse século tudo indica ser maior o cultivo dessa planta nas terras serra acima que nas do litoral, talvez porque na baixada costeira se reservassem as terras melhores para o cultivo de cana de açúcar. Não havia assim lavoura mais difundida (e mais frequentemente mencionada nos "inventários e testamentos") do que a representada pelas roças de mantimentos em que a mandioca era sem dúvida a dominante para o preparo da "farinha de pau" e da "farinha de guerra". Para transformar a mandioca das roças em farinha, os moradores do planalto dispunham das "rodas de ralar", "roda de ralar mandioca", "roda de ralar mandioca chapeada", "roda de ralar mandioca com seu veio de ferro", "roda de mandioca chapeada de latão". As prensas, os ralos, as rodas (todo o aviamento de preparação de farinha de mandioca) aparecem registrados, com extraordinária frequência, desde os fins do século XVI até as primeiras metades do XVIII (Bruno, 1977).

Também, desde 1596, os inventários e documentos paulistas mencionam roças de milho, um pedaço de milho ou milharada. E o milho é, dos produtos utilizados na alimentação (do homem e dos animais), o mais frequentemente registrado para além dos limites da primeira ocupação paulista. Causa surpresa a omissão do monjolo e da farinha de milho, sendo lícito talvez supor que, na região piratiningana, os milharais não fossem utilizados para a produção da farinha, limitando-se seu aproveitamento ao consumo pelos animais e à alimentação dos homens sob a forma de milho assado, de milho cozido, de curau e de pamonha. Entretanto, é o feijão, depois do milho, o produto alimentício mais mencionado nos registros de disponibilidade ou armazenamento que aparecem nos inventários e testamentos. Já os canaviais registram-se sob as denominações de "pedacinhos de cana de açúcar" ou "pedaço de canavial", utilizado como matéria prima para a fabricação do açúcar e da aguardente nas pequenas indústrias quase caseiras (Bruno,1977). Na parte concernente aos animais, a criação de suínos (a mais volumosa) dava margem ao preparo de produtos alimentícios que figuram, com frequência, como carne de porco salgada, carne de porco curada, carnes de porcos salgadas com sal do reino e "bem acondicionadas" e ainda a manteiga de porco (banha), que aparece guardada em panelas grandes, em potes ou em cabaças. Tudo isto feito nos pequenos sítios paulistanos de antigamente.

Estas atividades, por mais estranho que pareça e que se possa levar à interpretação de um isolamento dos indivíduos devido ao seu caráter quase autóctone, caracterizou algumas áreas de serviço e de sociabilidade. Nas casas da capital paulista, no período quinhentista, desenvolvidas à volta do colégio jesuítico e em cima de uma colina cercada por várzeas, comportaram-se estas tal qual numa "aldeia rural". 0 local, rodeado por uma cercadura defensiva e com algumas portas de acesso aos campos de pastagem para as roças de milho e mandioca, possuíam poucas ruas, estreitadas por becos com as suas moradas vazias durante a semana, pois os residentes labutavam nas tarefas do campo situado fora deste domínio. Quando estes domínios estouraram os limites do rocio aumentando o número de propriedades rurais além-sertão, as novas casas iriam ser favorecidas com uma arquitetura residencial bem mais peculiar.

A pequena casa urbana e também do campo tinham ambas seus organogramas funcionais, possuindo os mesmos critérios de morar no que tangia ao papel feminino, ao resguardo da família, na organização do trabalho, fazendo com que a planta da casa permanecesse por mais de duzentos anos a mesma e se expandindo "oeste afora". Isso significa que ao tangível às necessidades entre meio e práticas habitacionais, o enredo havia permanecido semelhante à uma vasta área ocupada por estes paulistas, no que Ellis Júnior (1948) denominou de "Paulistânia". As questões naturais e econômicas, mantendo-se sempre num comum acordo, influenciavam assim as de ordem cultural, não tendo o paulista mudado suas caraterísticas tão cedo e, quando mudadas, não deixaram de sofrer algumas resistências.

Isso sinaliza que o ato da simbolização que organizou a conduta coletiva (aliás, esta conduta coletiva que organizou o ato simbólico), propiciou uma forma específica de utilização do ambiente, que 
envolveu a produção de conhecimentos, técnicas construtivas e de comportamentos padronizados que mantiveram um padrão num arco temporal expressivo. No sentido deste comportamento, este ser humano conseguiu criar um ambiente artificial que, mesmo guardando certo padrão, quando modificado, transmitido ou reformulado, conseguiu se manter firme por ainda guardar algumas atividades culturais no que tange ao seu modo de vida. Assim, parece mais coerente, ao estudar a habitação paulista tradicional, fixar-se nas relações das atividades humanas para com a casa para compreender o seu espaço onde a técnica, quando manipula os recursos da natureza e satisfazendo as exigências de um complexo natural que rege a vida de um grupo, consegue dar mostras de como o ato simbólico envolve os objetivos deste grupo.

Logicamente que o meio influi com a disponibilidade dos materiais, com o clima, com a localização, mas é a capacidade humana em se deter na elaboração de algo a partir desses materiais (de uma forma que isto lhe sirva propriamente) é que parece ser de extrema importância quando se estuda os padrões arquitetônicos que se assemelham numa vasta área como foi o caso paulistano. Desta maneira, seria o caso de arriscar dizer que a experiência simbólica do espaço de ação paulista não seria um mero trabalho antropológico entre homem, natureza e artifícios à mão, e sim que esta relação, quando produz mecanismos de comunicação entre um homem e outro a partir do momento da descrição dos modos de construir, é descrever os limites territoriais estabelecidos e utilizados para aproximar os semelhantes. Reconhecer os materiais utilizados para a construção destas habitações e sua técnica construtiva não é uma relação meramente quantitativa, mas sim o ato de desvelar na lida (ação) para com estes materiais o percurso de um caminho que estabelece uma via de identificação. Via esta estabelecida com o trabalho realizado pelo ser (caipira) no mundo, ou seja, em seu território, no caso denominado Paulistânia.

\section{Paulistânia: o território em constante construção}

A "Paulistânia", na carência absoluta em termos de fonte de renda econômica e tendo em vista a descoberta dos caminhos auríferos, tornou-se uma clareira de influência tanto comunitária (ações e relações sociais) quanto de reconhecimento entre paisagem e ambiente provindo das andanças do habitante planaltino, passando a englobar áreas onde, mais tarde, ficariam conhecidas por sua atividade monocultora tanto açucareira nos séculos procedentes (XVII, XVIII e com mais força no XX) como cafeeira (século XIX). Além dos caminhos por terra, o transporte fluvial foi um dos métodos mais utilizados nesta fase histórica, mais precisamente a partir do século XVIII, ligando por comunicações regulares dois centros econômicos importantes: a região aurífera cuiabana com o mercado produtor e distribuidor do litoral paulista, designando-se para esta empreitada o nome de "monções" (Holanda, 1945).

Em virtude de causas econômicas que não lhe deixava alternativas, a capitania vicentina no seu início quinhentista, não tendo podido o seu litoral concorrer com a do norte (que se encontrava mais perto do caminho para a metrópole consumidora), ficou relegada à miséria, fazendo seus moradores buscarem a internação sertaneja. 0 planalto paulista, situado em região geográfica de clima mais temperado e frio, nada podia exportar para a Metrópole. Assim, não conseguia alimentar intercâmbio algum com Portugal e, dessa inação, só poderia resultar num isolamento autárquico com uma pobreza mais acentuada comparada às demais regiões do país naquele período. Além do mais, o habitante do planalto não possuía poderes aquisitivos para comprar qualquer mercadoria cara, como a provinda do ramo escravista. Neste viés, durante os dois primeiros séculos, o negro escravizado era um elemento quase ausente no planalto, colocando em pauta uma composição consanguínea mais particular à este ser humano da capitania sulina, ou seja, não se classificando igualmente como o mulato encontrado nas zonas nordestinas do país (Ellis Júnior, 1948). Desta forma, a parte cultivada desta região era muito pequena e, da mínima atividade agrícola, o seu efeito abrangia um consumo minúsculo, não havendo outro tipo de produção que requisitasse mão de obra abundante.

Além disso, subir a Serra do Mar só poderia ser feito por pessoas com grande força de vontade, sendo um desses elementos que serviu de "filtro que selecionou o habitante do sertão" (Ellis Júnior, 1948). A maioria que vencia estas intempéries eram homens, mesmo porque se destinava a mulher a cuidar da pequena roça e da casa enquanto o elemento masculino viajava. Na medida de sua entrada no sertão, este se ligou às mulheres índias, fazendo com que o cruzamento imediato resultasse no 
mameluco, herdando a toponímia paulista (além do sangue) a influência bugre. Os documentos são unânimes em registrar esse influxo na nomenclatura dos lugares geográficos, de modo que se pode bem ver como era grandiosa a exercida cultura e, consequentemente, a língua guarani.

Desta forma, "a gente da Paulistânia", como expressa Ellis Júnior (1948), em razão do apresamento, saturou de índios a região que foi, durante muito tempo, o entreposto fornecedor de mão de obra nativa ao nordeste açucareiro. Com tantas forças militando no mesmo sentido, o apresamento, tendo sido uma atividade econômica expressiva e explorando uma indústria que empolgava toda a população planaltina, constituía a base econômica regional. Com isso, o apresamento, dosado de patriarcalismo e da organização escravocrata, temperado e reequilibrado pela policultura e pela pequena propriedade imperante na "Paulistânia", modelou uma estrutura social mais ou menos homogênea, vide a própria consistência da bandeira como fenômeno planaltino condicionada amplamente pela mobilidade coletiva dos habitantes da Capitania do Sul, influenciando assim o seu quadro societário.

0 agrupamento de homens em prol de um benefício em comum (o índio), mediante a migração espacial, criou em São Paulo de outrora um comportamento deveras semelhante definindo não só as distâncias e caminhos que se percorreriam, mas, nitidamente, as ordens comunitárias e a psicologia social (Ribeiro, 1946). Um dos exemplos é a própria mística que envolvia o sertão. A demonologia ameríndia conjuntamente com o misticismo messiânico de origem ibérica teve largo influxo nesta última. A imaginação ardente dos bandeirantes, somado aos mistérios da terra mal explorada e dos animais nunca vistos, tornou o sertão um meio cósmico. A crença em seres sobrenaturais em locais repletos de acidentes geográficos também contribuía para explicações de cunho místico frente ao assombro mesológico. A própria vida errante e aventureira do bandeirante concorria para este desdobramento, criando lendas e superstições de grande popularidade e que influía na busca por sua existência. Vide as lendas sobre "lagos dourados" repletos de ouros, picos de montanhas e morros cujo brilho era constatado das mais variadas distâncias, onde ali mesmo poderia ser encontrado rubis ou esmeraldas.

0 prestígio da fauna e da flora e sua influência sob o intelecto deste ser não seria interrompido neste único ponto. $\mathrm{O}$ calendário humano condicionado por estes mesmo fatores distinguia o tempo por intermédio das estações das frutas de determinadas árvores. A expressão "tempo das frutas", segundo Ribeiro (1946), ficou tão usual que seu alcance ainda é utilizado, como no dizer: "o mês de dezembro é o das mangas". Aliás, esta associação de frutos, legumes, terra e tempo (dentre tantos outros fatores) fora adquirido desde épocas de "cata do ouro", onde se pode perceber a associação do fulvo metal com seu respectivo batismo por elementos da flora. As jazidas de ouro, por exemplo, assemelhando-se com as folhas da batata, herdariam o nome "batatal". Desta forma, cada aspecto da flora também teria suas respectivas lendas devido ao tempo de seu ciclo germinativo e todos eles, pela crença nativa, teriam seres protetores, tal qual uma "mãe".

Outro fato curioso é que as epidemias seriam associadas à crença de que os relâmpagos eram sinais destas mesmas ou eles próprios as traziam. As curas para estes males e de outros, entretanto, eram fáceis de serem encontradas na própria fauna, como no mel, nas raízes ou nas entranhas de alguns animais (Holanda, 1995). Animais estes que serviam não só de alimento, pois alguns de seus membros eram utilizados para o fabrico de utensílios domésticos. Por exemplo, do tatu se aproveitavam as orelhas para o feitio de alpercatas e do casco a confecção de cuias. Além do mais, o próprio ato de caçar gerava contos e lendas que poderiam ter alguma representação nas danças (catiras e cateretês) ou narrações para os demais do grupo. Nestas, entravam a narração não só do ato final, ou seja, a morte do animal, mas sim todo o preparativo para a ida à caçada, os lugares que foram vistos e passados e, logicamente, o prestígio adquirido na volta para casa com o espólio.

Entretanto, para uma simbolização consistente da Paulistânia, seria o correto a concentração sobre a localização das diversas rancharias pelos caminhos que lhe foram fendidos. Os roteiros feitos em direção à estes conjuntos de habitações se amalgamavam às plantações de milho, às criações de animais e ao tempo de jornada de uma rancharia à outra. Estas, perenes, porém, altamente estratégicas no que concerne à localização aos viajantes em busca de índio ou ouro. Coberto os seus telhados com palha e suas paredes com taipa, este era o lar do bandeirante que poderia demarcar a sua 
permanência no sertão pelo tempo das "monções das águas" e das "monções secas" (verão e inverno, respectivamente). Desta maneira, o bandeirante nada poderia fazer sem conhecer o período destas estações, pois prescindia saber qual a época exata de plantar o milho para viajar caso a fauna não lhe fosse favorável. Além do mais, o aguardo da maturação destas roças era representado naquela citada perenidade do seu rancho.

Assim, nas zonas de expansão, pouca dúvida permanece sobre que a maior parte das povoações como arraiais e vilas nasceu destes pousos denominados "rancharias" (Candido, 1964; Ribeiro, 1946), mais tarde sendo levados à cabo pelos núcleos de mineração. No território da Paulistânia, o forte, a fortaleza, a capela ou a igreja vieram posteriormente, visto a relativa autonomia da população planaltina como descreve Ellis Júnior (1926). Sua célula inicial de povoamento foram mesmo estes núcleos de ranchos, sendo estes de abastecimento, de produção e de fator econômico por excelência. Desta forma, o embrião da urbs paulista parece estar, inevitavelmente, mais relacionado com este tipo de ocupação territorial do que como tradicionalmente se estipula a literatura clássica sobre a formação das cidades brasileiras.

Estas rancharias localizavam-se nos caminhos e picadas como pontos de ligação, tais como as cidades atualmente. Constituíam-se de arquitetura rústica, em lugares que havia água consumível para a lavoura e pastagem de gados. Não se encontravam em lugares desertos, sendo estes denominados de "travessias". Com o aumento destes núcleos é que as cidades deste território foram surgindo. De tal modo que já é sabido o caráter itinerante do mameluco, muitas dessas rancharias foram deslocadas em razão principalmente das técnicas utilizadas no plantio e pastagem que cansavam e deixavam inférteis as terras ocupadas, mas isso não tira o prestígio da formulação de uma ocupação que se pautava, principalmente, em dois aspectos principais: o primeiro é o territorial, caracterizado pelo aspecto antropossociológico; e o segundo é o cronológico, este um fator preponderante para o reduto do ser.

Entretanto, na medida em que a economia colonial se desinteressava pelo índio e quando a atividade aurífera se exauriu, o indivíduo caracterizado por uma vida seminômade - morando nestes casebres denominados "ranchos" (denunciando a efemeridade da permanência no local) —, passou a se fixar nas antigas paragens dos caminhos pelos quais percorria. A ocupação dessas paragens deu origem a um tipo de formação territorial que compreende além de uma identificação entre os circundantes - posteriormente resultando num pertencimento ao lugar e ao grupo por laços de parentesco, de vizinhança e de cooperação mútua - a um reconhecimento topográfico e topológico. Esta expansão territorial da "Paulistânia" foi tão expressiva que, para abranger o enorme aumento de sua população e de sua atividade abastecedora, teve que dilatar sua área povoada, onde passou a englobar localidades mais distantes do velho núcleo piratiningano como: Botucatu, Tietê, Itapetininga, Campinas, Limeira, Piracicaba, núcleos estes fundados no século XVIII.

A partir do momento em que o bandeirante (em grande contato com os fenômenos da natureza) uma vez fixado, começa a se transformar num tipo humano que viveria do plantio e da colheita do seu alimento, além de conhecer os ciclos das estações anuais e as condições meteorológicas para realizar suas atividades, passaria a ser conhecido na literatura por "caipira" (Candido, 1964). Assim, o caipira é um homem em grande contato com a natureza, um indivíduo inserido numa economia de subsistência e que, mesmo com um comportamento peculiar de isolamento, ainda mantém um mínimo de sociabilidade com seus semelhantes. Encontrando-se na zona rural, exprime por sua localização um comportamento rústico, ou seja, um tipo de conservação dos costumes e tradições oriundos da miscigenação de raças lusitanas e indígenas.

Desta maneira, a expansão geográfica dos paulistas nos séculos XVI, XVII e XVIII, por exemplo, resultou não apenas na incorporação de território às terras da coroa portuguesa na América, mas na definição de certos tipos de cultura e de vida social. Estes foram condicionados em grande parte pelo grande fenômeno de mobilidade. Se se analisar que, em certas porções do grande território percorrido pelas bandeiras, as características culturais europeias recém-chegadas a este continente se desdobraram numa variedade subcultural do tronco português, este desmembramento formou um novo indivíduo e um novo tipo de aculturação com atividades sociais, culturais e lúdicas.

Neste viés, o ponto de partida para compreender essa situação deve ser buscado na própria natureza do povoamento paulista. Desta maneira, o bandeirismo para Candido (1964), por exemplo, pode ser 
compreendido de um lado como vasto processo de invasão ecológica e de outro como determinado tipo de sociabilidade com suas próprias formas de ocupação do solo. A combinação dos traços de dois elementos, que pareceriam tão distintos, não o foi desta maneira na composição do caipira. Obedeceria este homem tanto ao ritmo de vida do bandeirante quanto às características de uma cultura largamente permeada pelas práticas de presa e coleta do índio, herdando uma estrutura de vivência relativamente instável e dependendo (não raro) de certa mobilidade territorial.

Assim, para o caipira, herdeiro do modo de vida bandeirante, a agricultura itinerante também foi um recurso de extrema importância quando precisou estabelecer um equilíbrio entre as necessidades de sobrevivência à falta de técnicas capazes de proporcionar um rendimento maior de sua terra quando já se encontravam inférteis. Todavia, as técnicas e instrumentos rudimentares de trabalho desta cultura improvisada encontraram condições para sobreviver no momento em que também condicionavam uma coerente sociabilidade pautada na desnecessidade do trabalho compulsivo, favorecendo assim a preservação dos costumes da vida do homem do campo. Esta sociabilidade que se enquadrava num povoamento disperso, na verdade, não constituía um isolamento, mas sim uma congregação por cooperações vicinais e pela vida lúdico-religiosa denominada "bairro rural" (Candido, 1964; Fukui, 1979; Queiroz, 1973). Bairro rural este que expressa nitidamente a conservação antropológica, sociológica e psíquica do paulista, conformando uma acentuação de um modo de vida mais sedentário, mas sem deixar de lado o elemento que mais pautou o paulista tradicional: a itinerância, que sempre estava presente nas distâncias de uma casa a outro dos componentes do bairro.

\section{0 bairro: a identificação de um novo território}

0 bairro rural é a estrutura fundamental da sociabilidade caipira. Cabe a ressalva que este bairro é entendido como uma unidade de vivência pautada por laços de vizinhança e não como uma unidade habitacional urbana, ou seja, não se é concebido aqui o bairro rural como um mero apêndice à mercê da expansão das diversas freguesias e vilas que o englobariam mais tarde ao perímetro urbano (Marx, 1991). Assim dito, consiste, segundo Candido (1964), no agrupamento de algumas ou muitas famílias mais ou menos vinculadas pelo sentimento de localidade, pela convivência, pelas práticas de auxílio mútuo e pelas atividades lúdico-religiosas. As habitações podem estar próximas umas das outras sugerindo, por vezes, um esboço de povoado ralo ou podem estar de tal modo afastadas que pouco se pode notar a unidade que as congrega. Assim, a ideia de isolamento da vida caipira seria um erro. Em suas análises, Candido (1964) constata que poucos moradores destes bairros não eram integrados por este tipo de agrupamento de vizinhança.

Mas o que seria exatamente o bairro rural? Pode-se dizer que é uma porção de território onde se encontram grupos de casas afastadas do núcleo urbano e também uma das outras em distâncias variáveis. Entretanto, nos documentos paulistas do período colonial, "bairro" sempre aparecia como uma divisão administrativa de freguesia que é, por sua vez, subordinada a uma vila. Esta vila, portanto, era a sede de todo um determinado território, quase sempre vasto e com frequentes delimitações imprecisas (Candido, 1964; Marx, 1991). No mesmo viés, a freguesia supunha um núcleo compacto de habitação com uma igreja raramente suprida de sacerdote e o "bairro" era sempre designado como uma divisão que abrangia todos os moradores esparsos, podendo possuir capela ou cemitério.

Todavia, efetivamente, o bairro rural para o caipira abarca extensões, dimensões, aspectos físicos e determina um território por características topográficas e por um sentimento de localidade entre seus moradores, que dependeria do intercâmbio entre as famílias e as pessoas. Portanto, o bairro rural é um espaço em que os moradores têm consciência de pertencer, de fazer parte, formando uma unidade de vivências semelhantes. Consiste na convivência, na necessidade de cooperação (compromisso) o qual incide sob a noção de proximidade física, formando uma referencialidade que abarca todas as residências dos habitantes, assim como a igreja construída e mantida pelos próprios moradores, os encontros na venda para a compra de artigos que a economia de subsistência não supre e até mesmo a relação com o sagrado.

É desta forma que a palavra "bairro" abrange em si a unidade congregante da vida do caipira, pois enunciá-la significa evocar a origem das atribuições dos papéis sociais dentro do núcleo. Atualmente, 
também é muito comum esses bairros serem ligados a núcleos mais complexos como um município que, por vezes, pode ser subsidiado com os produtos advindos dos mesmos, sendo este município considerado como uma mera seção administrativa ou política. Há também a ligação de um bairro com outro, o que não seria de todo raro, pois se interligam por laços afetivos estabelecidos por consanguinidade ou pelos vários auxílios nos trabalhos realizados, podendo estes ser de cunho vicinal ou lúdico-religioso, formando assim uma espécie de região (Queiroz, 1973).

Além de distribuir os papéis sociais no âmbito das atividades desenvolvidas em seu núcleo, o bairro funciona deste modo porque no âmbito familiar seus papéis também são definidos. A sua unidade básica de vivência nunca se desconecta da noção dos papéis exercidos dentro da família. Curiosamente, a maioria dos casamentos da população residente desses núcleos, segundo Fukui (1979), é realizada entre pessoas conhecidas que tem seu sentimento de localidade enraizado e definido por se reconhecer quem habita nas regiões vizinhas. Ou melhor, pode-se dizer que a noção de região nunca é descolada do conhecimento sobre as pessoas, sabendo-se sempre quem mora no local a se destinar e qual é a organização familiar e sociocultural.

Para o caipira, sua noção de habitar também se resolve no binômio "campo-cidade", ou seja, a configuração espacial do núcleo urbano se diferencia agudamente da do bairro rural, tornando diferente para ele a forma de identificar os residentes da cidade. Além do mais, a distância dos núcleos urbanos (e até mesmo de outros bairros rurais) para o caipira é muito relativa, sendo que as pessoas podem estar a muitos quilômetros de distância uma das outras, porém, mantendo a relação que as definem como participantes do bairro e assim consideradas próximas ou até compadres. Entretanto, numa análise mais concentrada no âmbito interno do bairro rural, esta noção do "habitar caipira" fica mais esclarecida com o mutirão.

Quando o caipira habita sua terra com sua família, a qual lhe ajuda nos trabalhos necessários no plantio e na colheita, tem sempre perto de seu núcleo familiar uma capela a qual frequenta nos dias de missa ou festa - podendo ele ser o organizador desta festa - , e uma venda, onde compra algo que porventura lhe falte ou comercializa algum excedente de sua colheita. As distâncias guardadas entre uma casa à outra ou da capela e da venda determinam a assiduidade de trocas de cooperação mútua tanto entre vizinhos quanto no que concerne às atividades lúdico-religiosas. Isso cria uma noção de participação mais ativa nesses bairros rurais e, consequentemente, de pertencimento e de identidade. 0 crescimento demográfico também auxilia na multiplicação da quantidade de bairros. Na medida em que os filhos vão deixando a casa paterna, mudam-se para outros bairros ou fundam outros núcleos. Se este novo núcleo começa a se tornar mais extenso, outra capela pode ser erguida (muitas vezes dedicada ao mesmo santo) instituindo costumes semelhantes encontrados no bairro que moravam anteriormente e dando certa continuidade à tradição. Entretanto, mudar não é algo penoso para o caipira. Mudar significa simplesmente ir para outra localidade com a certeza de encontrar ou fundar um lugar semelhante ao qual deixou (Candido, 1964; Queiroz, 1973).

Neste viés, o bairro rural não é uma unidade fechada, altamente estática e nem mesmo excludente, pois basta que haja a participação do recém-chegado nas atividades que o local oferece, como as festas e as rezas, para que este seja integrado (Queiroz, 1973). Um exemplo seria o apadrinhamento pelo batismo ou o que se fazia nas festas religiosas quando indivíduos de diferentes famílias descobrem que tem o mesmo santo padroeiro. Levados a esse sentimento de semelhança, o morador do bairro, ganhando neste momento a alcunha de "compadre", já sabe que se tornou um membro ativo do local.

Outra forma de identificação dos habitantes do bairro (e também de percepção do espaço) pelo caipira é o mutirão (Caldeira, 1956). Essencialmente, o mutirão consiste na reunião de vários vizinhos a fim de ajudar alguém necessitado a efetuar determinado trabalho: construção de casas, roçada, plantio. Geralmente os vizinhos são convocados e o beneficiário lhes oferece alimento e uma festa quando o trabalho está encerrado. A remuneração direta não é realizada, pois a única obrigação entre os indivíduos de um mutirão é a moral em que fica o beneficiário de corresponder aos eventuais chamados dos que o auxiliaram (Caldeira, 1956; Candido, 1964). A necessidade de ajuda imposta pela técnica agrícola e a sua retribuição automática determina a formação de uma rede ampla de relações, ligando os habitantes do grupo de vizinhança e contribuindo para a sua unidade estrutural e funcional. 
Para ser convocado neste tipo de trabalho, o indivíduo tem que ser convidado. Dos feitios laborais ao vizinho necessitado, ao término da tarefa, aquele que foi convocado tem a certeza de estar incluído no território do bairro. Aliás, a noção de território deste bairro advém com estes chamados para o mutirão. Participar dele, mesmo que a distância de uma casa a outra seja grande, significa ser reconhecido como vizinho. Um fato curioso é que pela distância a ser vencida para se chegar às casas consideradas como pertencentes ao bairro rural, o participante ou o convocado tem que percorrê-lo em todas as direções, tendo assim a oportunidade de divisar seus contornos e conhecer localidades mais longínquas. 0 bairro assim vai sendo constituído como uma imagem mental que relaciona localidades, habitantes, comunidade e como um objetivo comum a ser seguido por meio de atos de agradecimento aos participantes e ao padroeiro (ou divindade).

No mutirão, pode-se notar uma relativa divisão de trabalho e o estabelecimento de uma liderança coordenadora. Vale a ressalva que tal divisão de trabalho está relacionada à cooperação vicinal, significando o estabelecimento de um sistema de favores que garante a economia local. Além desses ajutórios nos trabalhos lavorais, Candido (1964) explica que há nos bairros rurais uma solidariedade que se exprime pela participação nas rezas e nas festas caseiras para cumprimento de promessa, surgindo outro sistema comunitário: o espaço sobrenatural, elemento muito presente na representação identitária do grupo. A função do mutirão no bairro, além de uma reunião para o trabalho e consequentemente de festas que reforçam a coesão social, é também enriquecer os laços com o mundo espiritual. As festas, que são realizadas pós-feitio do mutirão, envolvem-se no culto aos santos padroeiros do bairro. Cada bairro ou cada família possui o seu santo padroeiro a quem se devota a fim de receber proteção, apadrinhamento e consolo. As cerimônias são sempre organizadas por um festeiro que seria o "dono da festa", passando este de casa em casa recolhendo as prendas ou o dinheiro para o leilão realizado na capela.

Tais eventos religiosos na zona rural, porém, são raros de serem realizados por um padre. Estes sempre foram em menor número no Brasil, fazendo com que os habitantes desta localidade se acostumassem com sua ausência (Candido, 1964; Queiroz, 1973). Porém, o mais interessante fica por conta da relação do caipira com respeito aos santos. 0 santo nunca é considerado um ser que está distante ou invisível, mas sim um ente que se corporifica na imagem que está sob o altar. A imagem não é simplesmente um objeto, ela é o próprio santo que passa a participar do mundo terreno sem por isso, em essência, deixar de fazer parte do sobrenatural.

Desta forma, no universo da religião, o maior interesse por parte do indivíduo é conversar com Deus, com os santos ou com qualquer outra entidade sobrenatural que lá habita. Desta relação percebida no campo religioso, esta mesma se pautaria horizontalmente. Se no céu tudo que se encontra é superior, pois remove o que é de poder comum da vida, a crença religiosa serviria como uma "ponte", uma "ligação direta" que parte de um plano inferior para um superior sem os "intermediarismos" que são comuns na vida terrena. Para tanto, oferece-se promessas, oferendas e sacrifícios, pois isso implica num comprometimento maior, mais amplo. A necessidade de se falar com Deus advém do fato de que, no plano terreno, sofre-se de tal maneira e têm-se tantas dúvidas que é preciso consultá-lo em busca de respostas para as "penitências". Com a religião, também se tenta promover uma comunhão que possa manter uma relação universal não só com a santidade, mas também com todos os homens e seres do universo.

A religião, de certo modo, pela sua vocação a reunir o sobrenatural ao espiritual, serve como regulador social e natural no mundo cotidiano, fazendo cessar as diferenças no plano terreno. Por ser desse modo, na cultura caipira, a religião explica-lhe de uma maneira mais satisfatória as diferenças no mundo dos mortais, como os episódios de doenças, calamidades, injustiças, oferecendo respostas a perguntas que não conseguem ser facilmente respondidas pela ciência. Assim, "religião", que na acepção da palavra tem o sentido de "laço", "aliança", "pacto", para o caipira serve como modo de ordenar seu mundo, proporcionando-lhe respostas para coisas mais complexas. Acredita o caipira que os santos intervêm na vida cotidiana, estando sempre presentes e prontos ao auxílio de quem o peça. Espera também dos santos não só a proteção em vida, mas após a morte, onde imagina que, junto com o santo, os seus parentes que morreram antes dele estejam lá para recebêlo, o que faz com que imagine o paraíso como algo semelhante ao que encontra na terra como, por exemplo, um bairro rural. 
Para ele, a morte é entendida como sendo uma migração (a qual fez por toda a vida) para outro grupo de vizinhança. Os parentes em vida, para auxiliá-lo nesta migração, fazem os ritos funerários conforme a tradição: penitências, rezas, ou seja, tudo o que for necessário para a viagem dar certo. É por isto que a noção de espaço pelo caipira nunca é avaliada em quilômetros. Sua avaliação se faz a partir das relações que mantém entre seus parentes e vizinhos, vivos ou mortos, encadeando até um grande respeito à figura do idoso devido ao fato de este estar mais próximo do parente que partiu. Desta forma, a relação de proximidade pessoal juntamente com a espacial consegue ser personificada ao ponto de, para certos indivíduos do grupo, serem eles os detentores do contato entre os mundos físico e espiritual. Assim, o mundo parece ao caipira, em decorrência dessas relações, pequeno e acessível, mas nunca igual.

Tais percepções o auxiliaram até na mais agravante de suas migrações. Quando o caipira, empurrado para o núcleo urbano pelo avanço agroindustrial, necessitou ressignificar seu modo de vida e se situar num novo ambiente, utilizou-se da ferramenta que mais lhe seria útil: a linguagem. Esta, um símbolo máximo da abstração de tempo e espaço, ou melhor, da reunião do "eu" com o mundo, fornecendo-lhe uma imagem altamente poética traduzida nas mais variadas formas em sua nova casa: no seu roçado e na criação de animais, no quintal e nas pequenas imagens do santo padroeiro do bairro tanto em altares dentro da casa como na fachada da entrada principal.

\section{Conclusão}

Não se pode aqui manter uma análise firme sobre uma essência última e caraterística do caipira e de seu habitat, pois, de fato, o mesmo é um simples ser humano. Desta forma o caipira é luta, mas uma luta por se tornar um legítimo habitante de um lugar que não lhe foi dado, mas criado, inventado, desfeito e recomeçado. Assim, toda a análise dos seus elementos distintos vão se pautando na busca de um hábito cultivado em sua morada. Hábito este revelador tanto do passado quanto do presente, o que realça ainda mais a dificuldade de sentidos numa existência tão absurda que é o "inventar a si mesmo no mundo". "Mundo" este visto não sob uma perspectiva global, abrangente, mas sob a perspectiva de um mundo característico por sua luta, pensado à maneira dos gregos que refletiam sempre "mundo" (Kosmos) como certo limite que instaura, que inicia e que coloca o homem a pensar verdadeiramente. Isto significa que é a partir de sua perspectiva que este ser humano abarca as demais diferenças de mundos, se reescrevendo assim no seu próprio. É por esta via que se acredita que o caipira, em sua luta existencial torna-se, por meio do construir de sua habitação, o seu destino singular.

Aliás, a temporalidade também entraria em pauta, sendo a efemeridade do tempo necessária para a caracterização do território caipira, pois se oferece como elemento propulsor para o fomento de elementos simbolizantes. Elementos estes que se denotam na perenidade dos ranchos, nas construções de aspecto rústico localizadas perto de declives ou até nas roças de milho, tendo este grão propriedades cíclicas que demarcam as jornadas empreendidas, como a granada de suas espigas relacionadas à distância de um rancho a outro. Além do mais, o milho também se relaciona com os aspectos de identidade, vide no dialeto caipira o nome "bandeira" designar algo por: "monte de espigas de milho na roça"; isto quando também assinalava os locais de acampamento àqueles que viajavam pela região, com a haste de alguma planta deixada de pé simbolizando o mastro de uma bandeira.

Aqui também vale uma ressalva quanto à este território da Paulistânia e seu enquadramento regional, comumente demarcado pelos estudiosos como sendo São Paulo, Paraná, Minas Gerais, Mato Grosso e Goiás. Certamente, não há dúvidas quanto a afirmação destes caminhos, ranchos, capelas, monjolos e plantações confeccionados pelo antigo paulista como sua área de ação. Mas, para pesquisas influenciadas por um determinismo de fundação de núcleos urbanos no Brasil (ou até de estudos mais calcados no exotismo da vida caipira ao modo de vida urbano contemporâneo), esta área ainda assim careceria de uma maior delimitação territorial para uma melhor análise que enquadrariam não só um tipo de homem, mas também certa paisagem cultural. Todavia, com este tipo de posicionamento deixa-se escapar o quanto o sertão caipira não seria somente conhecido por meio de estudos baseados na cartografia ou iconografia, mas também como um território que serviu de palco para o desenvolvimento de um drama existencial semelhante ao que ocorre em qualquer lugar do mundo. Este drama revela preocupações como, por exemplo: "o que é o tempo?", 
situações estas que transcendem qualquer delimitação territorial. Há aqui o reconhecimento de que existe o meio, a terra, o homem e a luta deste com os dois primeiros, mas crê-se que o caipira parece nutrir uma vontade de se fazer mais forte do que o poder do lugar propriamente, pois pela arrumação de sua casa, meio, homem e luta aparecem postos num mesmo joguete.

Também é a angústia desta situação que leva à uma ambiguidade, à um paradoxo presente constantemente nas relações comunitárias, existindo até apelos mais severos como os benzimentos e simpatias para a cura desse "mal", tentado tornar o impossível em possível. Entretanto, mesmo assim, não se sabe se o que cura ou o que revela é um ato do poder da vontade ou de alguma entidade algures. 0 homem caipira aqui, com estes mecanismos, acredita ordenar o mundo, tanto nos apetrechos para os benzimentos (folha de palma, copos com água, etc.) quanto pela revelação dita divina, transformando o benzedor em representante da entidade na terra. Mas tudo isso para perder-se de novo, porque não sabe dizer se o que chama de "mundo" é premeditado por algum deus ou por si próprio. Exemplo maior é a elevação de uma capela no bairro rural, onde ele tenta explicar a união do bairro e as situações das lides diárias pela vontade ou não do santo em atendêlas. Mesmo assim, os mundos terreno e sobrenatural criam uma diversidade temporal sem começo e fim, embaralhando mais uma vez a noção de bairro como uma unidade hermética, já que cada construção ali revela um tempo, uma atividade, um desocultar de acontecimentos de forma igualmente contemplativa.

Assim, a Paulistânia aqui não é vista somente como um território geográfico pautado pelas relações causais, mas palco aonde se desenrola (literalmente) o problema da construção humana, de um homem que tem a necessidade de se construir e de construir um mundo para si próprio, de colocar acentuações nas palavras e frases balbuciadas pelo absurdo da existência. Assim, esta casa paulista não deve se associar somente e necessariamente à um território em comum, mas com os problemas existenciais comuns, se tornando o homem (caipira) um ser que tem primeiramente a urgência de existir e não simplesmente de ocupar um lugar.

\section{Referências}

Bruno, E. S. (1977). O equipamento da Casa Bandeirista segundo os antigos inventários e testamentos. São Paulo: DPHAN.

Caldeira, C. (1956). Mutirão: formas de ajuda mútua no meio rural. São Paulo: Brasiliana.

Candido, A. (1999). Cururu. Revista Remate de Males. Recuperado de http://periodicos.sbu.unicamp.br/ ojs/index.php/remate/article/view/8635987/3696.

Candido, A. (1964). Os parceiros do Rio Bonito. Rio de Janeiro: J. Olympio.

Ellis Júnior, A. (1948). O ouro e a Paulistânia. São Paulo: Edusp.

Ellis Júnior, A. (1926). Raça de gigantes: a civilização no Planalto Paulista. São Paulo: Helios.

Fukui, L. F. G. (1979). Sertão e bairro rural. São Paulo: Ática.

Holanda, S. B. de (1945). Monções. Rio de Janeiro: Coleção Estudos Brasileiros.

Holanda, S. B. de (1995). Raízes do Brasil. São Paulo: Cia. das Letras.

Lemos, C. A. C. (1999). Casa paulista: história das moradias anteriores ao ecletismo trazido pelo café. São Paulo: Edusp.

Lemos, C. A. C. (1979). São Paulo: sua arquitetura, colônia e império. São Paulo: Nacional.

Lemos, C. A. C. (1969). Notas sobre a arquitetura tradicional de São Paulo. São Paulo: FAU-USP.

Marx, M. (1991). Cidade no Brasil: terra de quem? São Paulo: Edusp.

(C) Labor \& Engenho, Campinas [SP] Brasil, v.11, n.3, p.263-279, jul./set. 2017. 
Queiroz, M. I. P. de (1973). Bairros Rurais Paulistas. São Paulo: Livraria Duas Cidades.

Ribeiro, J. (1946). Folklore dos bandeirantes. Rio de Janeiro: José Olympio.

Schaden, E. (1962). Aspectos fundamentais da cultura guarani. São Paulo: DIFEL.

Zenha, E. (1970). Mamelucos. São Paulo: Empresa Gráfica da Revista dos Tribunais. 